\title{
PENGARUH PENGENDALIAN INTERN TERHADAP KEANDALAN LAPORAN KEUANGAN PADA PT. SAPTA SARI TAMA PALEMBANG Sugiharto ${ }^{1}$, Salman ${ }^{2}$
}

\author{
1, Dosen jurusan Akuntansi, Universitas Tridinanti, Sumatera Selatan \\ 2, Dosen jurusan Manajemen, Universitas Tridinanti, Sumatera Selatan \\ 1)Email : sugihartoabas05@gmail.com
}

\section{Submitted: \\ $10 / 11 / 2021$ \\ Revised: \\ $01 / 12 / 2021$ \\ Accepted: \\ $15 / 12 / 2021$ \\ Online-Published: \\ $31 / 12 / 2021$}

INFORMASI ARTIKEL

\begin{abstract}
ABSTRAK
Penelitian ini bertujuan melihat pengaruh penerapan pengendalian intern terhadap Keandalan Laporan Keuangan. Laporan keuangan memperlihatkan adanya indikasi piutang yang tidak sesuai dengan harapan dan terjadinya kelebihan atau kekurangan stock. Hal ini erat kaitannya dengan penerapan pengendalian intern yang dapat mencapai tujuan penerapannya yaitu keandalan laporan keuangan. Populasi dan sampel dalam penelitian ini adalah sebanyak 40 orang karyawan yang semuanya dijadikan populasi, dengan jenis dan desain penelitian yang digunakan ekploratif dan kausalitas serta rumusan masalah asosiatif yang menggunakan kuesioner. Berdasarkan hasil penelitian, pengendalian intern berpengaruh terhadap keandalan laporan keuangan, Kesimpulan dari penelitian ini menyatakan bahwa hipotesis yang menyatakan Pengendalian intern berpengaruh terhdap keandalan laporan keuangan dapat diterima.
\end{abstract}

Kata Kunci : Pengendalian Intern, Keandalan laporan keuangan

This research aims to see the effect of the implementation of internal control on the realiability of financial reporting. The financial reporting show indications of receivables that are not in line with expectations and the occurrence of excess or shortage of stock. This reporting is closely related to the implementation of internal control that can achieve the purpose of its implementation, namely the realiability of financial reporting. The population and sample in this research were 40 employees, all of which were used as a population. This research used exploratory and causality and the formulation of associative problems using questionnaires. Based on the results of the research, internal control affects the realiability of financial reporting. The conclusion of this research states that the hypothesis which states that internal control affects the realiability of financial reporting is acceptable.

Keywords: Internal Control, Realibility of Financial Reporting

\section{A. PENDAHULUAN}

Setiap perusahaan baik itu bisnis maupun sektor publik selalu membutuhkan informasi, informasi tersebut berupa informasi laporan keuangan, Informasi laporan keuangan terdiri dari : neraca, laporan perubahan equitas, laporan arus kas dan catatan atas laporan keuangan. Informasi laporan keuangan ini haruslah mencerminkan keandalan, ini berarti laporan keuangan terbebas dari pengertian yang menyesatkan sehingga dapat memberikan informasi yang real, yang dapat menilai feed back value, predivtive value dan time lines (Dedy Nordiawan, 2010:46).

Keandalan laporan keuangan dihasilkan dari penerapan pengendalian intern. Menurut Comittee of sponsoring Organization of The Treadway Commision pada tahun 1992, Pengendalian internal merupakan proses yang dipengaruhi oleh dewan Direksi, Manajemen dan karyawan yang dirancang dalam rangka memberikan jaminan bahwa organisasi dapat mencapai tujuannya. Dalam mencapai tujuan Pengendalian intern yang 
diterapkan oleh Dewan Direksi, manajemen, tujuan tersebut dapat dicapai melalui penerapan komponenkomponennya. Komponen-komponen pengendalian inter terdiri dari : Lingkungan pengendalian, penaksiran risiko, aktivitas pengendalian, informasi dan komunikasi serta pemantauan.

Bila kelima komponen ini diterapkan maka pada kahirnya akan dapat mencapai tujuan penerapan pengendalian intern salah satunya adalah Reliability of Financial Reporting (Mulyadi, 2015 : 21). Keandalan laporan keuangan menyatakan bahwa informasi dalam laporan keuangan terbebas dari pengertian yang menyesatkan dan kesalahan material, menyajikan setiap fakta secara jujur, serta dapat diverifikasi penggunaan informasi yang relevan, tetapi hakikat atau penyajiannya tidak dapat diandalkan, maka informasi tersebut secara potensial dapat menyesatkan. Hal ini dapat pula dikatakan bahwa informasi laporan keuangan dikatakan andal bila memenuhi kriteria; jujur, adanya substansi mengungguli bentuk, netralitas, pertimbangan sehat dan lengkap (Sofyan Syafri Harahap, 2008 :126).

Perusahaan PT. Sapta Sari Tama

Cabang Palembang merupakan suatu perusahaan yang bergerak dibidang distributor obat-obatan baik generik maupun non generik. Dalam pelaksanaan aktifitasnya melakukan penjualan guna menyalurkan obat-obatan ke berbagai daerah, misalnya : Bengkulu, Jambi, Pangkal Pinang dan lain-lain, dalam pelaksanaan aktifitas ini perlulah penyusunan berupa informasi laporan keuangan.

Penyusunan informasi laporan keuangan memperlihatkan adanya indikasi ketidak andalan laporan keuangan, hal ini bisa dilihat dari adanya piutang yang tidak sesuai harapan, adanya selisih stock gudang pada akhir stock opname yang memperlihatkan selisih lebih ataupun selisih kurang. Kondisi ini memperlihatkan akan pentingnya penerapan pengendalian intern. Hal ini senada dengan (Sugiharto, 2003:72) yang menyatakan terdapat pengaruh struktur pengendalian intern terhadap tujuan struktur pengendalian intern sebesar $67 \%$ dan dari tujuan struktur pengendalian intern ke kinerja bisnis Pasar Modern di Kota Bandung sebesar 32\%. Melihat kondisi pentingnya pengendalian intern yang dapat mencapai kepada tujuan penerapan pengendalian intern salah satunya adalah keandalan laporan keuangan, maka peneliti tertarik untuk meneliti dengan judul : Pengaruh Pengendalian Intern Terhadap Keandalan Laporan Keuangan Pada PT. Sapta Sari Tama Cabang Palembang.

Berdasarkan latar belakang diatas maka rumusan masalah yang dihadapi oleh PT. Sapta Sari Tama Cabang Palembang adalah : Apakah Pengendalian intern berpengaruh terhadap keandalan laporan keuangan Pada PT. Sapta Sari Tama Cabang Palembang ?

Adapun tujuan dari penelitian ini adalah untuk mengetahui dan menganalisa : Pengaruh pengendalian intern terhadap keandalan laporan keuangan pada PT. Sapta Sari Tama Cabang Palembang?

Hipotesis dalam penelitian ini adalah :

1. Terdapat pengaruh pengendalian intern terhadap keandalan laporan keuangan pada PT. Sapta Sari Tama Cabang Palembang

2. Tidak terdapat pengaruh pengendalian intern terhadap keandalan laporan keuangan pada PT. Sapta Sari Tama Cabang Palembang 


\section{B. METODE PENELITIAN}

1. Rancangan Penelitian.

Jenis dan desain penelitian yang digunakan menggunakan metode asosiatif yaitu suatu metode yang bertujuan untuk mengetahui pengaruh ataupun hubungan antara dua variabel atau lebih. (Singgih, 2007 : 101).

2. Variabel dan Definisi Operasional

Tabel 1. Variabel dan Definisi Operasional

\begin{tabular}{|c|c|c|c|c|}
\hline No & Variabel & Definisi Operasional & Indikator & Skala \\
\hline 1. & $\begin{array}{l}\text { Pengendalian } \\
\text { Intern }(X)\end{array}$ & $\begin{array}{l}\text { Proses yang dijalankan } \\
\text { oleh dewan komisaris, } \\
\text { manajemen dan perosen } \\
\text { lain entitas yang } \\
\text { didesain untuk } \\
\text { memberikan keyakinan } \\
\text { memadai tentang } \\
\text { pencapaian tiga } \\
\text { golongan ; Keandalan } \\
\text { pelaporan keuangan, } \\
\text { Efektifitas dan efisiensi, } \\
\text { Kepatuhan terhadap } \\
\text { hukum dan peraturan } \\
\text { yang berlaku } \\
\text { Mulyadi,2015 }\end{array}$ & $\begin{array}{ll}\text { - } & \text { Lingkungan } \\
& \text { pengendalian } \\
\text { - } & \text { Penaksiran } \\
& \text { risiko } \\
\text { - } & \text { Aktivitas } \\
& \text { pengendalian } \\
- & \text { Informasi dan } \\
& \text { Komunikasi } \\
\text { - } & \text { Pemantauan }\end{array}$ & Ordinal \\
\hline 2. & $\begin{array}{l}\text { Keandalan } \\
\text { Laporan } \\
\text { Keuangan (Y) }\end{array}$ & $\begin{array}{l}\text { Informasi dalam } \\
\text { laporan keungan bebas } \\
\text { dari pengertian yang } \\
\text { menyesatkan dan } \\
\text { kesalahan material, } \\
\text { menyajikan data secara } \\
\text { jujur serta dapat } \\
\text { diverifikasi PP no.71 } \\
\text { Th } 2010 \text {. }\end{array}$ & $\begin{array}{ll}\text { - } & \text { Penyajian jujur } \\
\text { - } & \text { Substansi } \\
& \text { mengunguli } \\
& \text { bentuk } \\
\text { - } & \text { Pertimbangan } \\
& \text { sehat } \\
\text { - } & \text { Netralitas } \\
\text { - } & \text { Lengkap }\end{array}$ & Ordinal \\
\hline
\end{tabular}

\section{Populasi dan sampel}

Populasi adalah seluruh objek penelitian (Suharsimi Arikunto, 2014 : 25). Dalam penelitian ini populasinya adalah seluruh karyawan yang ada di PT. Sapta Sari Tama Cabang Palembang sebanyak 40 Orang.

Sample dalam penelitian ini adalah sebanyak 40 orang karyawan di kantor PT Sapta Sari Tama Cabang Palembang diambil semuanya untuk dijadikan objek penelitian atau disebut penelitian populasi.

\section{Instrumen Penelitian}

Dalam penelitian ini alat yang digunakan penulis untuk mengumpulkan data adalah laporan piutang, dan persediaan serta melakukan tanya jawab dengan pegawai PT. Sapta Sari Tama Cabang Palembang dan permohonan pengisian kuesioner sesuai dengan kondisi yang sebenarnya terjadi, sehubungan dengan Pengendalian intern terhadap keandalan laporan keuangan. Setelah pengisian kuesioner dilakukan penjawaban kuesioner dengan menggunakan skala likert. Adapun skala likert dengan bobot skala sebagai berikut:
1. Sangat Setuju 5
2. Setuju 4
3. Cukup 3
4. Tidak Setuju 2
5. Sangat Tidak Setuju 1 


\subsection{Uji Validitas}

Validitas mempunyai arti sejauhmana ketepatan dan kecermatan suatu instrumen mengukur dalam melakukan fungsi ukurnya (Azwar, 2006 :172).

Pengukuran validitas menggunakan Corrected Item-Total correlation. melalui penggunaan SPSS, dimana dengan melihat hasil olahan spss yang nilai signya lebih kecil dari alpa 0,05.

\subsection{Uji Relibilitas}

Uji reliabilitas adalah seberapa besar derjat tes mengukur secara konsisten sasaran yang ingin diukur (Sukadji, 2000 :21). Suatu variable dikatakan reliabel jika nilai Cronbach's Alpha>0,60 jika sebaliknya data tersebut dikatakan tidak reliabel (Ghozali,2009:45)

\section{Teknik Analisis Data}

Terkik analisis data adalah mendeskripsikan teknik analisis apa yang akan digunakan oleh penelitian untuk menganalisis data yang telah dikumpulkan, termasuk pengujiannya. Menurut Sugiyono (2015 : 14) teknik analisa data dibagi menjadi analisa kualitatif dan kuantitatif.

\section{a. Analisis Kualitataif}

Analisis kualitatif yaitu data yang tidak berbentuk angka, Sebelum dianalisis, data kualitatif ini harus diskalakan, misalnya dalam skala ordinal atau nominal. Pada penelitian ini metoe yang digunakan adalah metode deskriptif, tujuannya yaitu suatu metode dalam meneliti sejumlah manusia, objek, kondisi, system, pemikiran atau suatu peristiwa pada masa sekarang tujuannya adalah untuk membuat deskriptif secara sistematis dan akurat mengenai fakta serta pengaruh antara variable.

\section{b. Analisis Kuantitatif}

Analisis kuantitatif yatu data data bentuk angka-angka hasil pengukuran atau perhitungan. Data disini menunjukkan adanya jumlah dari variable itu sendiri. Sebelum data diolah maka dilakukan uji asumsi klasik yang terdri dari :

\section{a. Uji Normalitas}

Pengujian normalitas data populasi dilakukan dengan menggunakan statistik Kolmogrov-Semirnov Test, alat uji ini biasa disebut dengan uji K-S dari program SPSS. Interpretasi normalitas data dihitung dengan cara membandingkan nilai Asymtotic Significance yang diperoleh dengan nilai $\alpha=0,05$. Jika Asymp.Sig $>0,05$, maka data dinyatakan berdistribusi normal.

\section{b. Uji Homogenitas}

Pengujian homogenitas pada penelitian ini dilakukan dengan menggunakan Chi-Square Test pada Program SPSS dengan taraf signifikansi $5 \%(\alpha=0,05)$. Interpretasi homogenitas data dihitung dengan cara membandingkan nilai Asymtotic Significance yang diperoleh dengan nilai $\alpha=0,05$. Jika Asymp.Sig $>0,05$, maka data dinyatakan homogen.

\section{c. Uji Linieritas}

Pengujian lineritas variabel bebas dengan variabel terikat dilakukan dengan menggunakan One-way Anova pada program SPSS dengan taraf signifikansi $5 \% \quad(\alpha=0,05)$. Interpretasi linieritas dilakukan dengan ketentuan jika $\mathrm{F}_{\text {hitung }}<$ $F_{\text {tabel }}$, maka variabel bebas dengan variabel terikat tersebut mempunyai hubungan yang linear.

\section{Pengujian Hipotesis}

a. Formula Hipotesis

Hipotesis :

$$
\text { 1. Ho: } b_{1} \pm 0 \text {, }
$$

2. Ha $: b_{1}=0$,

Keterangan :

$\mathrm{H}_{0}=$ Tidak terdapat pengaruh pengendalian intern terhadap keandalan laporan keuangan pada PT. Sapta Sari Tama Cabang Palembang.

$\mathrm{Ha}=$ Terdapat pengaruh pengendalian intern terhadap keandalan laporan keuangan pada PT. Sapta Sari Tama Cabang Palembang. 


\section{b. Kriteria Pengujian}

Dasar pengambilan keputusan yaitu dengan membandingkan statistik hitung dengan statistik tabel dengan $\alpha=$ 0,05 (signifikansi 95\%).

a. Untuk hipotesis tersebut dipergunakan uji $\mathrm{t}$

1. Probabilitas (sig.t) $\geq 0,05$; Ho diterima

2. Probabilitas (sig.t) $<0,05 ; \mathrm{Ha}$ diterima

\section{Koefisien Korelasi}

Nilai $r$ (Koefisien korelasi) ini berkisar antara $-1 \leq \mathrm{r} \leq+1$, semakin mendekati nilai 1 berarti semakin besar variabel independen $(\mathrm{X})$ mampu menerangkan variabel dependen (Y). Analisis terhadap nilai korelasi ini digunakan untuk mengetahui keeratan hubungan variabel bebas (X ) dapat menerangkan hubungan perubahan variabel (Y). Koefisien korelasi ini dapat bersifat hubungan yang positip, negatip ataupun tidak berhubungan.

\section{Koefisien Determinasi $\left(\mathbf{R}^{2}\right)$}

Untuk mengetahui koefisien penentuan (koefisien determinasi) dilakukan penghitungan $\mathrm{R}^{2}$ sehingga dapat ditentukan tingkat keandalan laporan keuangan. Dari koefisien determinasi ini merupakan kuadrat dari koefisien korelasi $\left(\mathrm{R}^{2}\right)$ bisa memberikan arti besarnya pengaruh variabel $\mathrm{X}$ terhadap variabel $\mathrm{Y}$.

\section{HASIL DAN PEMBAHASAN}

1. Uji Validitas dan Reliabilitas

a. Uji Validitas

Pada hasil olahan data menunjukkan hasil uji validitas terhadap populasi 40 karyawan dapat diketahui bahwa pengendalian intern menunjukkan data yang valid. Valid ini dapat dilihat dari hasil olahan data SPSS versi 24 pada lampiran dimana nilai signya lebih kecil dari alpa (0,05). Terdapat pula data pengendalian intern yang tidak valid karena nilai signifikansinya lebih besar dari alpa 0,05. Dan data yang tidak valid ini dikeluarkan untuk tidak diolah dalam pengujian pengaruh pengendalian intern terhadap keandalan laporan keuangan.

\section{b. Uji Reliabilitas}

Reliabilitas dilihat dari hasil output SPSS dengan melihat hasil nilai alpha cronbach. Nilai alpha cronbach yang lebih besar dari 0,6 maka dapat dinyatakan reliabel.

Tabel 2 Hasil Uji ReliabilitasVariabel Pengendalian Intern (X) dan Keandalan Laporan Keuangan (Y)

\begin{tabular}{|c|c|c|c|}
\hline Variabel & $\begin{array}{c}\text { Nilai } \\
\text { Alpha } \\
\text { Cronba } \\
\text { ch }\end{array}$ & $\begin{array}{c}\text { N } \\
\text { Of } \\
\text { Ite } \\
\text { ms }\end{array}$ & $\begin{array}{c}\text { Keterang } \\
\text { an }\end{array}$ \\
\hline $\begin{array}{c}\text { Pengendal } \\
\text { ian Intern } \\
(\mathrm{X})\end{array}$ & 0,768 & 14 & Reliabel \\
\hline $\begin{array}{c}\text { Keandalan } \\
(Y)\end{array}$ & 0,817 & 14 & Reliabel \\
\hline
\end{tabular}

Sumber :Hasil olahan spss versi 24 


\section{Analisis Statistik Deskriptif}

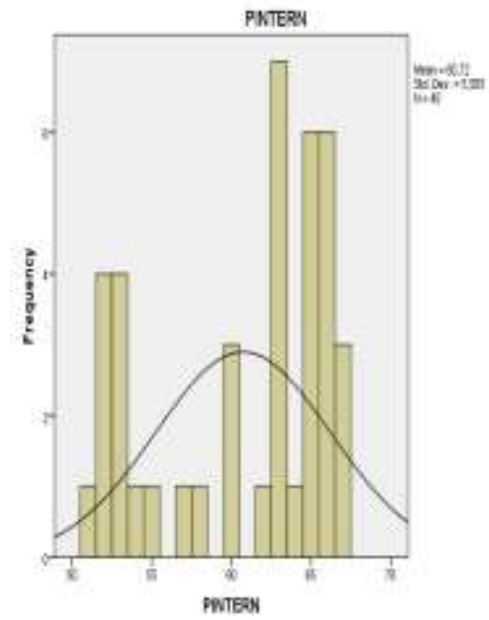

Dari hasil olahan data dapat dinyatakan bahwa variabel pengendalian intern dan keandalan laporan keuangan memiliki sebaran normal, hal ini dilihat dari kurva normal yang membentuk distribusi normal.

\section{Analisis statistik inferensial}

\subsection{Uji persyaratan Analisis}

\section{a. Uji Normalitas}

Pengujian normalitas dilakukan dengan menggunakan statistik uji kolmogrov semirnov. Dari hasil uji didapatkan kedua variabel tersebut adalah asympsignya lebih besar dari alpa $(0,05)$

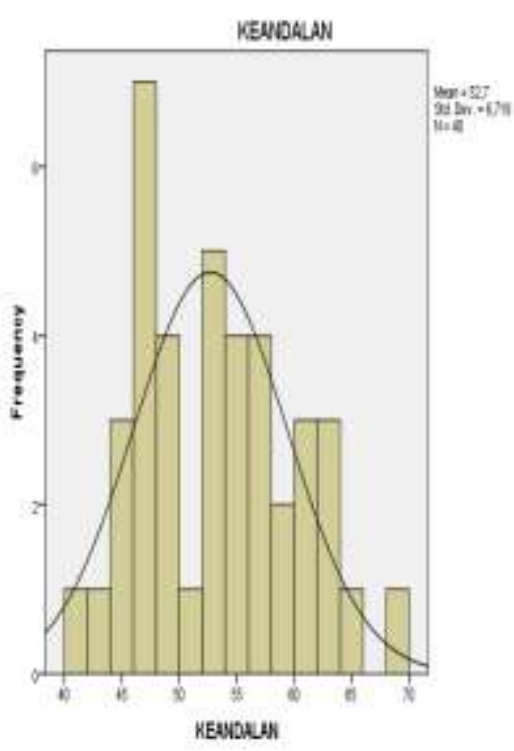

maka dapat dikatakan kedua variabel berdistribusi normal. Hal ini dapat dilihat pada tabel dibawah ini :

Tabel 3 Rangkuman hasil uji normalitas

\begin{tabular}{|l|l|l|l|l|}
\hline No & Variabel & $\begin{array}{l}\text { Nilai } \\
\text { Asymsig }(2 \\
\text { tailed) }\end{array}$ & Alpa =0,05 & Kesimpulan \\
\hline 1 & Pengendalian Intern (X) & 0,172 & 0,05 & Normal \\
\hline 2 & Keandalan (Y) & 0,355 & 0,05 & Normal \\
\hline
\end{tabular}

Sumber : Hasil olahan data melaui spss versi 24,00. 


\section{b. Uji homogenitas}

Pengujian homogenitas dilakukan menggunakan uji chi square. Uji ini dilihat dari asimsig chi square. Asimsig

Tabel 4Rangkuman hasil uji homogenitas

\begin{tabular}{|l|l|l|l|l|}
\hline No & Variabel & $\begin{array}{l}\text { Nilai Asymsig } \\
(2 \text { tailed })\end{array}$ & Alpa =0,05 & Kesimpulan \\
\hline 1 & $\begin{array}{l}\text { Pengendalian Intern } \\
(\mathrm{X})\end{array}$ & 0,221 & 0,05 & Homogen \\
\hline 2 & Keandalan (Y) & 0,740 & 0,05 & Homogen \\
\hline
\end{tabular}

Sumber : Hasil olahan data melaui spss versi 24,00

\section{c. Uji Linearitas}

Uji linearitas garis regresi dan simpulannya berdasarkan tingkat alpha menggunakan harga koefisien signifikansi. Apabila nilai signifikansi yang digunakan untuk menolak atau menerima Ho, maka nilai koefisien harus dibandingkan dengan tingkat alpa=0.05. Kesimpulan yang harus diambil yaitu model regresi berbentuk linear, diterima jika signifikansi dari deviation from linierity > dari alpa $=0,05$ sebaliknya tidak linier jika kurang dari alpa. Untuk chi square lebih besar dari alpa $(0,05)$ maka dapat dikatakan homogen. lineairty variabel tersebut adalah 0,349 dikatakan linier.

\section{Analisis Regresi linier sederhana} Tama Palembang.

Tabel 5 Hasil Uji Analisis RegresiLinier Sederhana).

\section{Coefficients $^{\mathrm{a}}$}

\begin{tabular}{|c|c|c|c|c|c|c|}
\hline \multirow{2}{*}{\multicolumn{2}{|c|}{ Model }} & \multicolumn{2}{|c|}{$\begin{array}{c}\text { Unstandardized } \\
\text { Coefficients }\end{array}$} & \multirow{2}{*}{$\begin{array}{c}\begin{array}{c}\text { Standardized } \\
\text { Coefficients }\end{array} \\
\text { Beta }\end{array}$} & \multirow[b]{2}{*}{$\mathrm{t}$} & \multirow[b]{2}{*}{ Sig. } \\
\hline & & B & Std. Error & & & \\
\hline 1 & (Constant) & 54.865 & 11.286 & & 4.848 & .000 \\
\hline & PIntern & .394 & .117 & .536 & 3.356 & .002 \\
\hline
\end{tabular}

a. Dependent Variable: Keandalan lebih besar dari alpa $(0,05)$. Maka dapat

1. Pengaruh pengendalian intern terhadap keandalan laporan keuangan pada PT. Sapta Sari

Dari tabel di atas persamaan regresi linear untuk pengaruh pengendalian intern terhadap keandalan laporan keuangan adalah :

$\mathrm{Y}=54.865+0,394 \mathrm{X}+$ e. Dari persamaan ini dapat diartikan bahwa konstanta sebesar 54.865 akan memberi pengertian bahwa jikan pengaruh pengendalian intern terhadap keandalan laporan keuangan PT. Sapta Sari Tama adalah konstanta sama dengan nol (0), maka besarnya kemampuan keandalan pada PT. Sapta Sari Tama 54.865 satuan. Hal ini menginformasikan bahwa pengendalian intern yang terdriri dari ; lingkungan pengendalian, penaksiran risiko, informasi dan komunikasi, aktivitas pengendalian dan monitoring memiliki pengaruh yang sangat signifikan terhadap keandalan laporan keuangan. Semakin tinggi perbaikan peningkatan pengendalian intern maka semakin tinggi pula peningkatan keandalan laporan keuangan.

Hal lainnya yaitu $X$, merupakan koefisien regresi dari variabel pengendalian intern sebesar 0,394 mempunyai arti bahwa bila terjadi perbaikan pengendalian intern terhadap 
keandalan laporan keuangan PT. Sapta Sari Tama sebesar 1 satuan, maka akan terjadi peningkatan keandalan laporan keuangan sebesar 0,394 satuan dengan asumsi variabel lainnya konstan atau tetap.

Model Summary

\begin{tabular}{|l|r|r|r|rr|}
\hline Model & \multicolumn{1}{|c|}{$\mathrm{R}$} & R Square & \multicolumn{2}{|c|}{$\begin{array}{c}\text { Adjusted } \mathrm{R} \\
\text { Square }\end{array}$} & \multicolumn{2}{|c|}{ Std. Error of the Estimate } \\
\hline 1 & $.536^{\mathrm{a}}$ & .287 & .261 & & 2.796 \\
\hline
\end{tabular}

a. Predictors: (Constant), Pintern

b. Dependent Variable: Keandalan

Dari tabel tersebut dapat dilihat bahwa koefisien korelasi pengendalian intern terhadap keandalan sebesar 0,536. Hal ini memberikan arti bahwa hubungan (Korelasi) pengendalian intern terhadap keandalan laporan keuangan adalah

\section{Coefficients}

\begin{tabular}{|c|c|c|c|c|c|c|}
\hline \multirow{2}{*}{\multicolumn{2}{|c|}{ Model }} & \multicolumn{2}{|c|}{$\begin{array}{c}\text { Unstandardized } \\
\text { Coefficients } \\
\end{array}$} & \multirow{2}{*}{$\begin{array}{c}\begin{array}{c}\text { Standardized } \\
\text { Coefficients }\end{array} \\
\text { Beta }\end{array}$} & \multirow[b]{2}{*}{$\mathrm{t}$} & \multirow[b]{2}{*}{ Sig. } \\
\hline & & B & Std. Error & & & \\
\hline 1 & (Constant) & 54.865 & 11.286 & & 4.848 & .000 \\
\hline & Pintern & .394 & .117 & .536 & 3.356 & .002 \\
\hline
\end{tabular}

a. Dependent Variable: Keandalan.

Berdasarkan tabel 7 di atas diperoleh $t_{\text {hitung }}$ sebesar 3.356. Dengan menggunakan tingkat signifikansi $(\alpha)$ sebesar 0,05 dan derajat kebebasan n2maka diperoleh nilai $t_{\text {tabel }} 1,68$ dengan demikian dapat ditarik kesimpulan bahwa Ho ditolak karena berdsarkan perhitungan uji t di peroleh bahwa $t_{\text {hitung }}>t_{\text {tabel }}$ yaitu $3,356>1,68$. Hal tersebut merupakan positip dengan tingkat keeratan hubungan yang kuat.

\section{Uji Hipotesis}

Tabel 7. Hasil uji t Statistik

signifikansi $\alpha \leq 0,05$ yang berarti $\mathrm{H}_{\mathrm{o}}$ ditolak dan Ha diterima yang menyatakan pengendalian intern berpengaruh terhadap keandalan laporan keuangan pada PT. Sapta Sari Tama Cabang Palembang.

7. Koefisien determinasi $\left(\mathbf{R}^{2}\right)$

Tabel 8. Hasil Uji Koefisien

Determinasi $\left(\mathbf{R}^{2}\right)$

kriteria penerimaan $\mathrm{Ha}$ atau nilai

Model Summary

\begin{tabular}{|l|r|r|r|r|}
\hline Model & \multicolumn{1}{|c|}{$\mathrm{R}$} & $\mathrm{R}$ Square & $\begin{array}{c}\text { Adjusted R } \\
\text { Square }\end{array}$ & \multicolumn{2}{|c|}{ Std. Error of the Estimate } \\
\hline 1 & $.536^{\mathrm{a}}$ & .287 & .261 & 2.796 \\
\hline
\end{tabular}

a. Predictors: (Constant), Pintern

b. Dependent Variable: Keandalan

Dari tabel 8 di atas diperoleh nilai

28,7\%. Artinya besarnya pengaruh koefisien determinasi $\mathrm{R}^{2}$ Sebesar 0,287= pengendalian intern (X) terhadap 
keandalan laporan keuangan (Y) sebesar $28,7 \%$ sedangkan sisanya $71,3 \%$ dipengaruhi oleh faktor-faktor lain diluar penelitian ini.

\section{SIMPULAN DAN SARAN}

\section{Simpulan}

1. Pengendalian intern bepengaruh terhadap keandalan laporan keuangan. Hal ini dapat dilihat dari hasil olahan data SPSS dimanaa nilai t signifikansi 0,002 lebih kecil dari alpa yaitu dibawah 0,05. Pengendalian intern juga mempunya korelasi /keeratan hubungan yang kuat dan memiliki kontribusi yang cukup tinggi sebesar 0,536. Korelasi ini memberikan arti bahwa bila pengendalian internnya tinggi maka keandalan laporan keuangan juga akan semakin tinggi.

2. Berdasarkan hasil pengujian hipotesis dengan menggunakan uji $t$ dapat ditarik kesimpulan bahwa Ho ditolak karena $t_{\text {hitung }}>t_{\text {tabel }}$. Hal tersebut merupakan kriteria penerimaan $\mathrm{Ha}$. Yaitu Pengendalian intern berpengaruh terhadap keandalan laporan keuangan.

3. Pengaruh pengendalian intern terhadap keandalan laporan keuangan belum berjalan dengan efektif, hal ini terlihat dari jawaban kuesioner yang menujukkan bahwa lingkungan pengendalian kurang begitu diperhatikan oleh pimpinan sehingga komponen-komponen pengendalian intern lainnya tidak berjalan dengan efektif.

\section{Saran}

- 1 Lingkungan pengendalian harus diperhatikan dan diterapkan secara efektif karena hal ini landasan bagi berjalnnya komponen-komponen pengendalian intern yang lain, seperti ; penaksiran risiko, aktivitas pengendalian, informasi dan komunikasi serta monitoring yang bila diterapkan secara efektif dapat menuju kepada andalnya laporan keuangan.

2. Perlunya perhatian terhadap kendala informasi yang relevan dan andal yaitu unsur materialitas dan keseimbangan antara karateristik kualitatif yang merupakan masalah pertimbangan profesional.

3 Untuk peneliti selanjutnya perlu diteliti variabel-variabel lainnya yang dapat mempengaruhi keandalan laporan keuangan.

\section{E. DAFTAR RUJUKAN}

Arrens. Alvin A, And James K.Loebbecke, 2010, Auditing an Integrated Approach, New jersey, Prentice Hall, Inc

Agoes, Sukrisno, 2004, Auditing (Pemeriksaan Akuntansi), Universitas Indonesia, Jakarta.

Abdul, Halim. 2008. Auditing (DasarDasar Audit Laporan Keuangan). Unit Penerbit dan Percetakan STIM YKPN, Yogyakarta.

Al haryono jusup. 2014. Auditing (Pengauditan Berbasis ISA).Sekolah Tinggi Ilmu Manajemen YKPN Yogyakarta.

Azwar, 2006, Statistik Untuk Penelitian Salemba Empat Jakarta

Bacal Robert, 2002, Performance Management (Alih Bahasa Dharma \& Irawan), PT. Gramedia Pustaka Utama, Jakarta

Dedy Nordiawan, 2010, Akuntansi Sektor Publik, Penerbit Salemba Empat Jakarta.

Ghozali, Imam, 2009. Aplikasi Analisis Multivariate Dengan Program 
SPSS, Edisi Keempat, Penerbit Universitas Diponegoro.

Irawan, Prasetya, 2007. Penelitian kualitatif dan kuantitatif untuk Ilmu-Ilmu Sosial, DIA FISIP UI, Jakarta.

Jurnal Ilmiah Aset, Maret 2020, hal. 9-18 Vol. 22 No. 1 ISSN 1693-928X DOI: 10.37470/1.022.1.02, Analisis Pengaruh Lingkungan Pengendalian Terhadap Keandalan Laporan Keuangan, Universitas Diponegoro Semarang

IAPI, DSP. 2013. Standar Pfofesional Akuntan Publik. Jakarta : Salemba Empat.

Kanaka Pura Direja, 2014, Auditing, Penerbit LPFE Yogyakarta

Mulyadi. 2015. Auditing. Buku 1 Edisi 6. Jakarta: Salemba Empat Jakarta.

Messier et.all. 2006, Auditing dan Asuurance Services " A Systematic Approach”. Salemba Empat Jakarta

Peraturan Pemerintah no. 71 Tahun 2010 Standar Akutansi Pemerintahan

Sugiharto, 2003, Tesis, Pengaruh Struktur Pengendalian Intern Terhadap Tujuan Struktur Pengendalian Intern dan Kinerja Bisnis Pasar Modern di Kota Bandung, Universitas Padjadjaran Bandung, Tidak dipublikasikan

Sugiyono, 2015, Metode Penelitian Bisnis, Penerbit Alfa Beta Bandung

Sanusi, Anwar. 2011. Metodelogi Penelitian Bisnis. Salemba Empat. Jakarta.

Sukrisno, 2010, Audit Manajemen, Penerbit STM YKPN, Yogyakarta
Siswanto Sutojo, 2014, Manajemen Audit, Penerbit Salemba Yogyakarta

Suswinarno, 2012.Aman dari Risiko dalam Pengadaan Barang/Jasa Pemerintah. Jakarta:Visimedia.

Sugiono, 2004, Pedoman Penelitian, Alfabeta, Bandung

Sofyan Syafri, 2008, Teori Akuntansi Salemba Empat Jakarta

Suharsimi Arikunto, 2014, Statistik Non

Parametrik, Penerbit Erlangga Jakarta

Tim Penulis Universitas Tridinanti Palembang 2008, Buku Pedoman Penulisan Skripsi dan Laporan Akhir, Universitas Tridinanti Palembang 